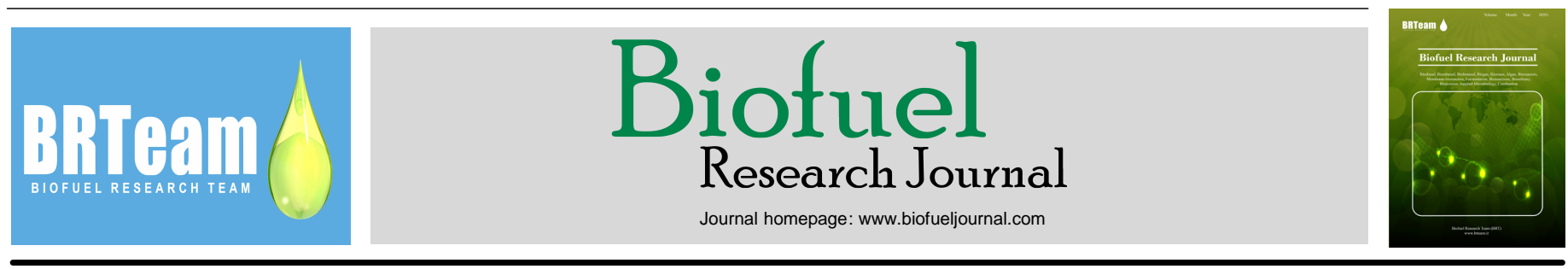

Original Research Paper

\title{
Energy and environmental assessments of bioethanol production from Sri Kanji 1 cassava in Malaysia
}

\author{
M. Hanif ${ }^{1}$, T.M.I. Mahlia ${ }^{1,2, *}$, H.B. Aditiya ${ }^{3}$, M.S. Abu Bakar ${ }^{2}$ \\ ${ }^{1}$ Department of Mechanical Engineering, Universiti Tenaga Nasional, 43000 Kajang, Selangor Malaysia. \\ ${ }^{2}$ Faculty of Integrated Technologies, Universiti Brunei Darussalam, Jalan Tungku Link, Gadong BE1410, Brunei Darussalam. \\ ${ }^{3}$ Department of Mechanical Engineering, University of Melbourne, VIC, Australia.
}

\section{HIGHLIGHTS}

$>$ Energy and GHG balances of Sri Kanji 1 cassava bioethanol were assessed.

$>$ Net Energy Balance and Net Energy Ratio were found to be $25.68 \mathrm{MJ} / \mathrm{L}$ and 3.98 , respectively.

$>$ Production and distribution of $1 \mathrm{~L}$ of Cassava Fuel Ethanol could reduce GHG emissions by $73.2 \%$.

$>$ Ethanol production process was the main contributor to the total life cycle GHG emissions by $72.09 \%$.

\section{GRAPHICAL ABSTRACT}

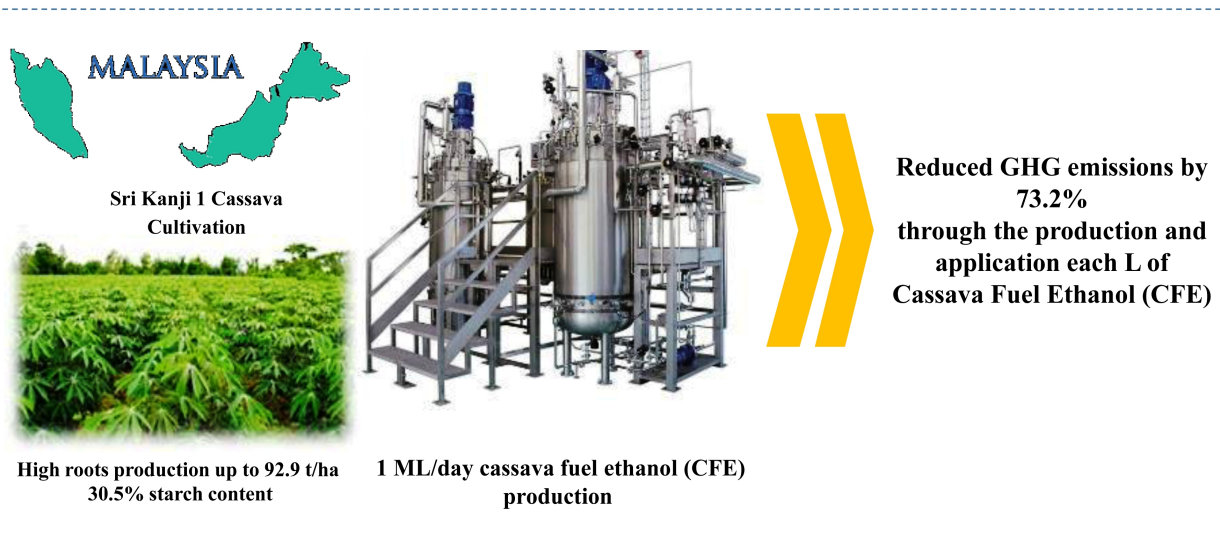

\section{ARTICLE INFO}

\section{Article history:}

Received 11 August 2016

Received in revised form 25 January 2017

Accepted 9 February 2017

Available online 1 March 2017

\section{Keywords:}

Sri Kanji 1 Cassava

Bioethanol

Energy balance

GHG balance

Life cycle assessment

Malaysia

\begin{abstract}
According to the Malaysia's biofuel policy, renewable fuels are crucial for energy sustainability in the transportation sector in the future. This study was aimed to evaluate the potential of bioethanol production from Sri Kanji 1 cassava in Malaysia in terms of energy efficiency and renewability, as well to estimate the potential greenhouse gas (GHG) emissions reduction in $\mathrm{CO}_{2}$ equivalent. Bioethanol production process from cassava includes cassava farming, ethanol production, and transportation in which the primary energy consumption was considered. The Net Energy Balance (NEB) and Net Energy Ratio (NER) of 25.68 $\mathrm{MJ} / \mathrm{L}$ and 3.98, respectively, indicated that bioethanol production from Sri Kanji 1 cassava in Malaysia was energy efficient. From the environmental perspective, the GHG balance results revealed that the production and distribution of $1 \mathrm{~L}$ of Cassava Fuel Ethanol (CFE) could reduce GHG emissions by $73.2 \%$. Although found promising in the present study, Sri Kanji 1 cassava as bioethanol feedstock should be further investigated by constructing an actual ethanol plant to obtain real life data.
\end{abstract}

* Corresponding author at: Tel.: +60-3-7967-5228

E-mail address: indra@uniten.edu.my,ttmi.mahlia@gmail.com

Please cite this article as: Hanif M., Mahlia T.M.I., Aditiya H.B., Abu Bakar M.S. Energy and environmental assessments of bioethanol production from Sri Kanji 1 cassava in Malaysia. Biofuel Research Journal 13 (2017) 537-544. DOI: 10.18331/BRJ2017.4.1.3 


\section{Introduction}

The main source of energy in Malaysia was oil until the energy crisis in the late 1970's. This has urged the Malaysian government to search for alternative resources such as natural gas, coal, and hydro. However, since the 1990's, the consumption of fossil-based energy carriers and the consequent $\mathrm{CO}_{2}$ emissions have been on the rise in Malaysia. Statistically, it is estimated that $97 \%$ of the annual total domestic $\mathrm{CO}_{2}$ emissions comes from fossil fuel consumption. In terms of fuel consumption, transportation sector is a major energy consumer in Malaysia, accounting for nearly $40 \%$ of the nation`s energy consumption (Mahlia et al., 2012a and b). In 2006, Malaysia made ample efforts to research and develop biodiesel as an alternative to fossil-diesel fuel for compression ignition (CI) engines (Masjuki et al., 2006; Kalam et al., 2008; Husnawan et al., 2009a and b; Jayed et al., 2011; Ong et al., 2012; Silitonga et al., 2013; Ong et al., 2014). B5 (95\% diesel and 5\% biodiesel) has been used commercially since July 2011 and the government was set to increase the percentage of biodiesel in the fuel (Lim and Teong, 2010). But later the policy of increasing biodiesel inclusion was put on hold.

Another promising energy replacement is bioethanol, a form of liquid fuel which can be produced from biomass and is suitable to replace conventional gasoline. Commonly bioethanol is blended with gasoline and is used in internal combustion engine (ICE) without any engine modifications. Many studies have reported on the use and performance analyses of ethanol as fuel substitute for ICEs (Cooney et al., 2009; Milnes et al., 2010). The fuel conversion efficiency, brake power, and brake specific fuel consumption of $10 \%$ ethanol blend is reportedly similar to that of neat gasoline (Curtis et al., 2008). Others claimed that the brake thermal efficiency was increased while fuel consumption was decreased when blending gasoline with $20 \%$ ethanol compared with neat gasoline (Siddegowda and Ventakesh, 2013). In terms of greenhouse gas (GHG) emissions, 10\% ethanol blend was found to lead to lower emissions in comparison with gasoline (Frazier). Moreover, the high octane number and high latent heat of vaporization of ethanol could result in excellent anti-knock qualities (Mahlia et al., 2012b). Schifter et al. (2011) argued that fuel consumption was lower when ethanol was included in gasoline in spite of the less energy content of the fuel blend, suggesting the overall positive effects of ethanol inclusion in gasoline on combustion efficiency.

Bioethanol is generally produced from starch crops by liquefaction and sacharification of starch using alfa-amylase and glucoamylase enzymes. The sugar slurry then undergoes the fermentation process by bacteria, yeast, or other fermenting microorganisms. In Malaysia, energy crops available for ethanol production are rice, corn, and cassava. It should be noted that crops selection for ethanol production is country-specific and depends on factors such as food shortage, production cost, as well as supply and demand. In this study, cassava one of the major Malaysia's food crops which can be planted on marginal land, was selected as bioethanol feedstock. The major advantages of cassava over rice and corn are tolerant to poor environmental conditions, possibility of all year long planting and harvesting, high root productivity, continuous improvements of high yield varieties, less input requirements for planting and harvesting, high quantity and quality of carbohydrates, highest energy content per acre among starchy crops, and high ethanol yield per acre (Kuakoon, 2011).

In Malaysia, particularly in the transportation sector, bioethanol is yet to be considered as environmentally-friendly fuel and could be instrumental in reducing the country`s reliance on fossil fuels. Net energy balance (NEB) and life cycle assessment (LCA) have been proven to be suitable methods to evaluate the environmental sustainability of biofuels to identify opportunities for environmental efficiency improvements. NEB could also be used to measure the energy effectiveness and efficiency of bioethanol production systems. It is worth quoting that both methods have been widely used to assess a number of bioethanol systems but as expected, the results reported vary. According to a study, the NEB of corn-based bioethanol was greater than 1 (Shapouri et al., 2004). Positive NEB values indicate that a process is energy efficient. Other feedstocks such as sugarcane, cane molasses, and cassava have also been studied in terms of their NEB and LCA (Dai et al., 2006; Farrell et al., 2006; Kim and Dale, 2006; Leng et al., 2008). In terms of emissions reduction, a recent study conducted in Belgian found that the production of bioethanol from wheat could reduce GHG emissions by $91 \%$ compared with conventional gasoline (Belboom et al., 2015). In case of cassava bioethanol, emissions reduction stood at around 58\% without any energy allocations (Numjuncharoen et al., 2015).
Recently, Khatiwada et al. (2016) verified that bioethanol production from cane molasses in Indonesia resulted in an NEB of $17.7 \mathrm{MJ} / \mathrm{L}$ of ethanol and had a potential to reduce emissions by $67 \%$ compared with gasoline. It is worth highlighting that the environmental and energy features of a given bioethanol production process vary due to their dependency on several factors including crop residues, farming practices, and industrial operation and technology. In an effort to improve the performance of cassava, Malaysian Agriculture Research and Development Institute (MARDI) introduced a new cassava variety, i.e., Sri Kanji 1 capable of producing higher root and starch compared with the normal variety of Black Twig. More specifically, Sri Kanji 1 can produce roots up to 92.9 t/ha with a 30.5\% starch content (NurulNahar and Tan, 2012). Therefore, Sri Kanji 1 could be considered as a promising bioethanol feedstock worthwhile. Nevertheless, Malaysia is yet to deploy and conduct a complete assessment of bioethanol production from Sri Kanji 1 cassava.

Therefore, through this study Cassava Fuel Ethanol (CFE) was evaluated to realize if it could serve as a feasible and practical alternative energy carrier. To produce CFE, cassava ethanol with a purity of more than $99.5 \%$ is blend with gasoline at $10 \%$ volume (E10). Cassava ethanol have to fulfil two criteria in order to serve as a suitable substitute for the existing conventional gasoline, namely positive NEB with regards to both production and use as well as reduced GHG emissions (Nguyen et al. 2007). In line with that, the objectives of the present study were to evaluate the energy balance and renewability of CFE in Malaysia based on the LCA approach, and to estimate the GHG emissions of CFE in Malaysia. Moreover, a sensitivity analysis was also conducted to determine the critical potentials for further improvements.

\section{Methodology}

The efficiency of a given bioethanol system is determined through the differences between the bioethanol energy content and the fossil fuels consumed in the production process. Energy required for growing cassava is mostly from infinite solar energy, therefore, it was exempted in the NEB assessment. In this study, LCA was used to estimate the environmental performance of CFE according to the framework described by the International Organization for Standardization (ISO) consisting of four steps: (1) study goal and scope definition; (2) environmental loads identification and quantification; (3) loads potential environmental impacts evaluation; and (4) available options to reduce environmental impact assessment (Guinee et al., 2002; ISO 14040, 2006). The analysis included cassava cultivation, transportation, as well as ethanol production up to distribution.

\subsection{CFE life cycle: system boundary and data sources}

The CFE system boundary determines the system interrelation with the environment based on the input and output energy. CFE system includes cassava farming, ethanol production and transportation. Cassava cultivation sector represents all steps involved in cassava farming which includes land preparation, planting, crop maintenance (fertilization, weed control) and harvesting. The data required were obtained from the Ministry of Agriculture and Agro-based Industry Malaysia (MOA) and MARDI (Cassava Farming Package, 2012; MARDI, Malaysia Agriculture Research and Development Institute). The Sri Kanji 1 cassava variety is generally harvested 12 months after planting which is usually done manually. The raw data concerning Sri Kanji 1 cassava cultivation per hectare are tabulated in Table 1 .

The source of organic fertilizer presented in Table 1 was completely decomposed animal manure. Organic fertilizer was applied one week before the stem plantation, while NPK fertilizers were applied three weeks after plantation (Cassava Farming Package, 2012).

Due to the unavailability of an actual ethanol plant in Malaysia, the energy consumption for ethanol production process was adapted from the literature (Nguyen et al., 2007). The production of ethanol from raw cassava includes raw material preparation (milling and mixing), ethanol production, distillation, and dehydration.

Different transportation facilities were considered to transport all input and output materials of the CFE system by taking into account different transport distances. Due to the unavailability of relevant information 
regarding transportation, the values were estimated based on types of vehicles and travel distances.

Table 1.

Input materials for Sri Kanji 1 cassava cultivation per hectare (Cassava Farming Package, 2012).

\begin{tabular}{lll}
\hline \multirow{2}{*}{ Activity } & \multicolumn{2}{c}{ Input } \\
\cline { 2 - 3 } & Material & Input Rate \\
\hline Land preparation & Organic fertilizer & $5 \mathrm{t} / \mathrm{ha}$ \\
Herbicide application & Metaolachlor & $4 \mathrm{~L} / \mathrm{ha}$ \\
Cuttings treatment & Fluometuron & $2 \mathrm{~kg} / \mathrm{ha}$ \\
Fertilization & Copper Sulfate & $2 \%$ \\
Weed control & NPK Fertilizer 12:6:22:3 & $500 \mathrm{~kg} / \mathrm{ha}$ \\
\hline
\end{tabular}

\subsection{CFE feasibility study}

The data for CFE assessment such as details associated with fertilizers, herbicides, labor, etc. were obtained from the MOA (Cassava Farming Package, 2012). Energy values for transportation sector were estimated, and for ethanol production process were adapted from the study conducted by Nguyen et al. (2007). Other required data were obtained from other previously published reports (Dai et al., 2006; Nguyen et al., 2007; Silalertruska and Gheewala, 2009). The assessment was made based on energy balance and environmental impacts.

\subsection{Primary energy input estimation}

In LCA, the assessment of energy balance is conducted by accounting the primary energy values, which is are the accumulation of fuel energy content and fuel-cycle energy consumption. The energy content in the fuel consumed by the CFE system was acquired from the Malaysia Energy Commission (National energy balance, 2012). The fuel primary energy values were estimated from the input efficiency coefficient of fossil-based fuel from the Institute of Food and Agricultural Sciences (IFAS, 1991).

In Malaysia, most of the fertilizers are domestically manufactured. The energy required for production of fertilizers and herbicides was adapted from Helsel (1992) and Audsley et al. (2009), respectively. The energy requirements included those of the manufacturing, packaging, marketing, transportation, and distribution activities. The energy requirements for fertilizer and herbicide production used in cassava cultivation are presented in Table 2 and Table 3 , respectively.

Table 2.

Energy requirements to produce, pack, transport, and use inorganic fertilizer (Helsel, 1992).

\begin{tabular}{lccc}
\hline & \multicolumn{3}{c}{ Energy requirement $(\mathbf{M J} / \mathbf{k g})$} \\
\cline { 2 - 4 } & Nitrogen, $\mathbf{N}$ & Phosphate, $\mathbf{P}_{2} \mathbf{O}_{\mathbf{5}}$ & Potassium, $\mathbf{K}_{2} \mathbf{O}$ \\
\hline Production & 69.53 & 7.70 & 6.40 \\
Packaging & 2.60 & 2.60 & 1.80 \\
Transportation & 4.50 & 5.70 & 4.60 \\
Application & 1.60 & 1.50 & 1.00 \\
Total & 78.23 & 17.50 & 13.80 \\
\hline
\end{tabular}

To evaluate the energy corresponding to agriculture labor (cassava cultivation and harvesting), "Total Food Consumed (TFC)" method has been suggested (Ozkan et al., 2004; Romanelli and Milan, 2005; Dai et al., 2006). TFC method considered $2.3 \mathrm{MJ} / \mathrm{h}$ of human labor energy equivalent. Nevertheless, if more information is available, "Life-Style Support Energy" (LSSE) method is suggested to evaluate human labor (Odum, 1983). The energy equivalent of human labor was estimated by taking into account labor
Table 3.

Energy requirements for herbicides production (Audsley et al., 2009).

\begin{tabular}{lccc}
\hline & \multicolumn{3}{c}{ Energy requirement $(\mathbf{M J} / \mathbf{k g})$} \\
\cline { 2 - 4 } & Paraquat & Fluometuron & Metoalachlor \\
\hline Inherent energy & 144.5 & 190.7 & 127.7 \\
Process energy & 314.9 & 163.9 & 148.1 \\
\hline
\end{tabular}

cost and the energy consumed per dollar of economic activity (energy intensity of the economy). By applying the minimum agricultural wage and energy intensity in Malaysia, the energy equivalent of $12.2 \mathrm{MJ} / \mathrm{h}$ was determined for farming labor in Malaysia (Malaysia Energy Commission., 2011; Cassava Farming Package, 2012).

For transportation of input materials and products, different modes of transportation were utilized for different purposes. Larger vehicles with larger payload were used for city delivery and smaller ones were used for farm delivery due to the accessibility reasons. Estimations related to transportation are tabulated in Table 4. The location of the fertilizer manufacturer was considered in the northern region of the country, i.e., Kedah while most of the cassava cultivations are located in Selangor. Therefore, the average distance from the cultivation field to the fertilizer manufacturer was estimated at about $300 \mathrm{~km}$. Ethanol plants are usually located at the industrial site, which are on average about $100 \mathrm{~km}$ away from the agricultural areas.

Table 4.

Process, transportation mode, distance travel, and fuel economy involved in transporting input materials and products.

\begin{tabular}{|c|c|c|c|c|}
\hline Process & $\begin{array}{c}\text { Vehicle } \\
\text { type }\end{array}$ & $\begin{array}{c}\text { Load } \\
(\mathrm{kg})\end{array}$ & $\begin{array}{r}\text { Distan } \\
(\mathbf{k m})\end{array}$ & $\begin{array}{c}\text { Fuel Economy } \\
(\mathbf{k m} / \mathbf{L})^{*}\end{array}$ \\
\hline $\begin{array}{l}\text { Transporting fertilizers and } \\
\text { herbicides from production } \\
\text { plant to fields }\end{array}$ & $\begin{array}{c}\text { Lorry } \\
\text { Light Truck }\end{array}$ & $\begin{array}{c}20,000 \\
5,000\end{array}$ & $\begin{array}{c}300 \\
2\end{array}$ & $\begin{array}{l}2.55 \\
4.25\end{array}$ \\
\hline $\begin{array}{l}\text { Transporting fresh cassava } \\
\text { from farm to ethanol } \\
\text { production plant }\end{array}$ & $\begin{array}{l}\text { Light truck } \\
\text { Dump truck }\end{array}$ & $\begin{array}{c}5,000 \\
20,000\end{array}$ & $\begin{array}{c}2 \\
100\end{array}$ & $\begin{array}{l}4.25 \\
2.55\end{array}$ \\
\hline $\begin{array}{l}\text { Transporting ethanol from } \\
\text { production plant to distribution } \\
\text { center }\end{array}$ & Tank lorry & 10,000 & 100 & 1.7 \\
\hline
\end{tabular}

* Source: National Research Council, 2010

Table 5.

Direct materials and energy contribution in the CFE production.

\begin{tabular}{lc}
\hline Item & Consumption/1000 L bioethanol \\
\hline 1) Cassava cultivation & \\
Fertilizers & \\
$\quad$ Nitrogen & $3.15 \mathrm{~kg}$ \\
$\quad$ Phosphorous & $1.58 \mathrm{~kg}$ \\
$\quad$ Potassium & $5.79 \mathrm{~kg}$ \\
Herbicides & \\
$\quad$ Paraquat & $0.03 \mathrm{~kg}$ \\
$\quad$ Fluometuron & $0.11 \mathrm{~kg}$ \\
$\quad$ Metaolachlor & $0.08 \mathrm{~kg}$ \\
Labor used for farming & $37.4 \mathrm{Man}-\mathrm{hours}$ \\
Diesel used for farm machinery & $2.6 \mathrm{~L}$ \\
2) Ethanol production & \\
Electricity & $100 \mathrm{kwh}$ \\
Coal & $260 \mathrm{~kg}$ \\
3) Transportation (diesel) & \\
Fertilizers & \\
Fresh cassava & $0.513 \mathrm{~L}$ \\
Ethanol & $24 \mathrm{~L}$ \\
\end{tabular}




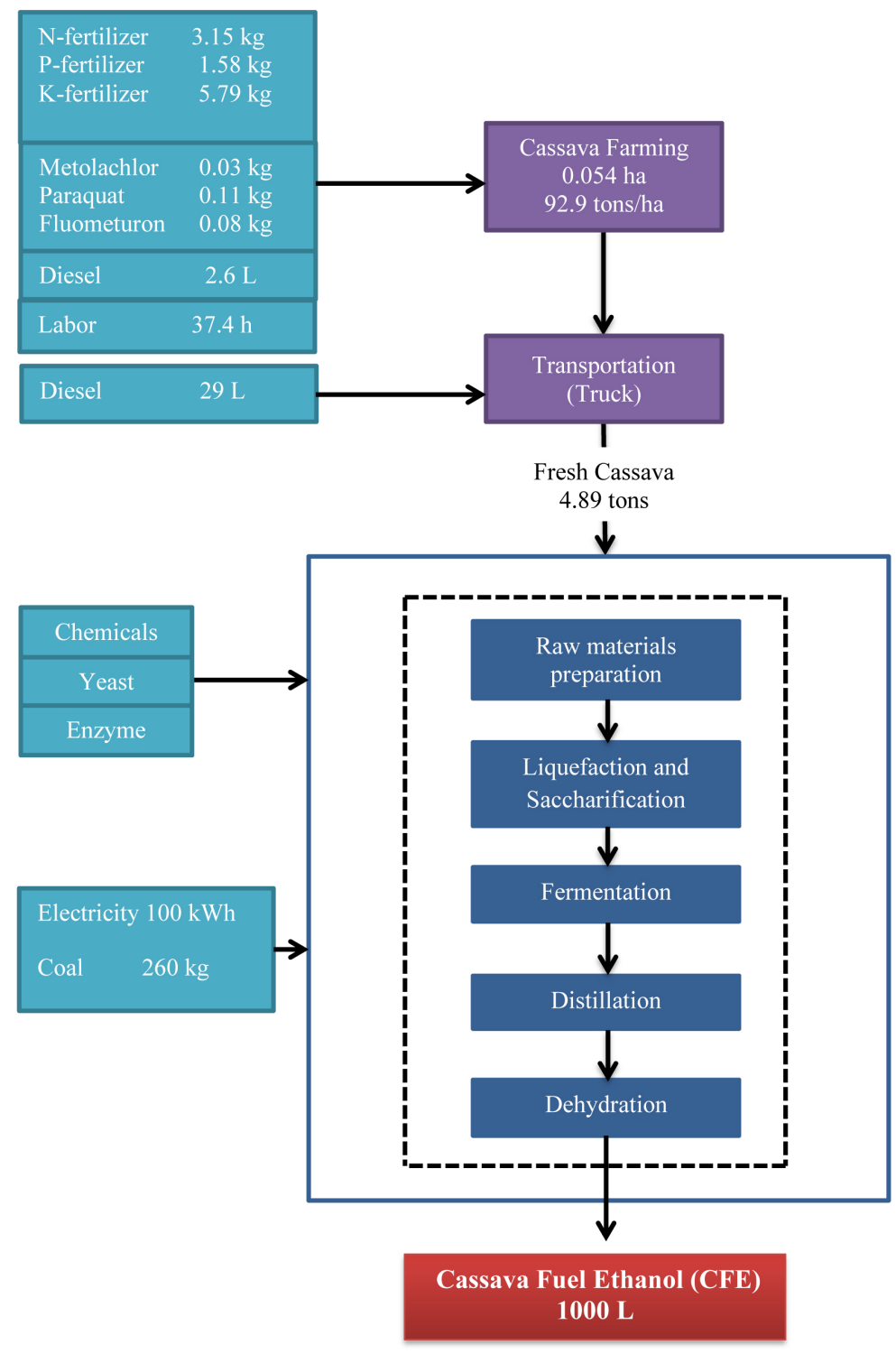

Fig.1. Materials flow diagram and system boundary for 1000 L CFE production.

A summary of direct energy input and other materials associated with energy calculations in the CFE system is shown in Table 5. Direct material and energy flows associated with the CFE system are presented in Figure 1.

The inputs in cassava cultivation were based on the data obtained from MOA and MARDI (NurulNahar and Tan, 2012; Cassava Farming Package, 2012). The inputs for ethanol production process were adapted from the neighbour country, i.e., Thailand, where ethanol is produced at commercial scale (Nguyen et al., 2007). Lastly, the inputs for the transportation sector were obtained by estimating distances between the cultivation areas and the ethanol plant, as well as the fertilizer manufacturer.

In the ethanol production process, raw materials were first reduced in size or ground to increase the specific surface area for enhanced reaction of water and enzymes with starch materials. The ground feedstock then underwent liquefaction and saccharification processes through which starchy materials were trasformed into fermentable sugars using alfa-amylase and glucoamylase (Nguyen et al., 2007). Yeast was then added to the slurry and $15 \%$ ethanol, carbon dioxide, and slid wastes (including raw materials and yeast cells) were produced (Sorapipatanaa and Yoosina, 2011). After the ethanol fermentation stopped, the fermented mash was transferred into a multi-column distillation system to heat up and separate the ethanol produced. The product stream leaving the distillation column contained about $95 \%$ ethanol by volume and the bottom stream included the stillage, containing nonfermentable solids and water (Wang et al., 2016). The hydrous ethanol was then transferred into a molecular sieve system for further purification. Eventually anhydrous ethanol with a purity of higher than $99 \%$ by volume was produced (Sorapipatanaa and Yoosina, 2011).

\subsection{Energy analysis}

NEB is the best criterion to evaluate energy savings potential of a given system (Henke et al., 2005). For NEB analysis, the fossil energy contribution for the production of bioethanol and conventional gasoline should be taken into account. Moreover, bioethanol and conventional gasoline substitution ratio needs to be specified. Henke et al. (2005) used an ethanol and conventional gasoline substitution ratio of 0.65 based on the energy content of both fuels. However, it should be noted that although 
bioethanol has less energy content per L compared with and conventional gasoline, it has a higher octane number allowing greater compression ratios and hence, more efficient thermodynamic operation in ICEs could be expected. Therefore, an appropriate substitution ratio should be based on fuel economy and not on the energy content. The substitution ratio for ethanol and conventional gasoline (in E10) in terms of fuel economy is 1:0.89 (Nguyen and Gheewala, 2008). According to the above-mentioned assumptions, the derived reference value of $34.4 \mathrm{MJ} / \mathrm{L}$ was calculated for the $\mathrm{CFE}$ blend. This value was used to compare the amount of fossil energy inputs in the CFE production cycle (Eq. 1).

$N E B=$ Reference value - Fossil energy input

To better describe the efficiency of cassava ethanol, the Net Energy Ratio (NER) was determined as follows (Eq. 2):

$N E R=\frac{\text { reference value }}{\text { fossil energy inputs }}$

\subsection{GHG balance}

GHG emissions in this study were evaluated in terms of $\mathrm{CO}_{2}$ equivalent which describes the amount of global warming by using the functionally equivalent concentration of $\mathrm{CO}_{2}$ as the reference. The $\mathrm{CO}_{2}$ equivalent emissions were calculated by multiplying the amount of inputs consumed to produce $1 \mathrm{~L}$ of ethanol by the respective emission factor $(\mathrm{EF})$

\subsubsection{GHG emissions from the fossil fuel consumed}

In cassava cultivation process, the GHG emissions are mostly contributed by the crop maintenance via application of fertilizers and herbicides. The emission factors for the production of fertilizers and herbicides were taken from Biograce (2011) to estimate the GHG emissions of cassava cultivation. For ethanol production process, the GHG emissions were adapted from the study conducted by Nguyen and Gheewala (2008).

Evaluating man-power using LSSE technique resulted in GHG emissions caused by the fossil energy consumed to support labor energy. The product of fossil energy consumed with the ratio of net domestic GHG emissions to net fossil fuel consumption was used to estimate GHG emissions caused by the man-power used (Malaysia Energy Commission., 2011; Sarkar et al., 2013). The emission from the transportation sector was estimated by multiplying diesel consumption by the EF provided by the International Sustainability and Carbon Certification (ISCC) (ISCC, 2011).

\subsubsection{Emissions reduction}

The total emissions reduction when ethanol was used as alternative for conventional gasoline was estimated by using a substitution ratio of 0.89 . The $\mathrm{CO}_{2}$ produced by conventional gasoline was estimated using GREET 1.7 (Wang, 2006). The differences in $\mathrm{CH}_{4}$ and $\mathrm{N}_{2} \mathrm{O}$ emissions of the vehicles fuelled with E10 were net zero. Therefore, only $\mathrm{CH}_{4}$ and $\mathrm{N}_{2} \mathrm{O}$ production from raw material cultivation and ethanol production process were considered in GHG reduction evaluation. Net avoided emission can be represented as shown below (Eq. 3):

Net avoided emissions $=$ CFE life cycle GHG production

$$
\text { - total emissions reduction }
$$

\subsubsection{Sensitivity analysis}

Sensitivity analysis was used to forecast the outcome of a selection that is different from the primary estimation. In better words, sensitivity analysis is an investigation to reveal the dissimilarity of the anticipated results with the primary assumption on which the forecast was based. Sensitivity analysis also provides estimations on uncertainties, for example, changes in raw material cost, which can influence the feasibility of a given project. Investigated elements were raw material cost, discount percentage, introductory capital cost, and operation cost.

\section{Results and Discussion}

\subsection{Energy analysis}

Energy analysis calculations were performed by applying substitution ratio based on fuel economy rather than energy content. With substitution ratio of 0.89 as mentioned earlier, the reference value used for ethanol substitution was $34.4 \mathrm{MJ} / \mathrm{L}$. The results obtained on the CFE production in Malaysia are presented in Table 6. The positive NER of 3.94 indicated that bioethanol production from Sri Kanji 1 cassava was energy efficient. In better words, for every unit of energy used, about 4 times more energy output would be generated. Moreover, the production of $1 \mathrm{~L}$ of CFE substituting for $0.89 \mathrm{~L}$ of conventional gasoline would results in $25.68 \mathrm{MJ}$ of energy savings or an equivalent of $0.67 \mathrm{~L}$ of conventional gasoline.

Table 6.

Energy balance of bioethanol production from Sri Kanji 1 cassava in Malaysia.

\begin{tabular}{lc}
\hline Items & $\begin{array}{c}\text { Fossil energy inputs } \\
\text { (MJ/L ethanol) }\end{array}$ \\
\hline 1) Cassava Cultivation & 0.99 \\
a) Fertilizers & 0.34 \\
$\quad$ Nitrogen & 0.24 \\
$\quad$ Phosphorous & 0.03 \\
$\quad$ Potassium & 0.07 \\
b) Herbicides & 0.04 \\
$\quad$ Paraquat & 0.01 \\
$\quad$ Fetalachlor & 0.02 \\
c) Labor used & 0.01 \\
d) Diesel for machinery & 0.5 \\
2) Ethanol production & 0.11 \\
a) Electricity & 6.69 \\
b) Coal & 0.33 \\
3) Transportation & 6.36 \\
a) Fertilizers & 1.04 \\
b) Herbicides & 0.02 \\
c) Ethanol & 0.86 \\
\hline Total energy inputs & 0.16 \\
\hline Reference value (CFE) & 8.72 \\
\hline NER & 34.4 \\
NEB & 3.94 \\
\hline
\end{tabular}

To predict the outcome of the energy balance when the values of the studied parameters turn out to be different compared with the planned key predictions, a sensitivity analysis was done. Figure 2 illustrates the sensitivity analysis derived from the CFE system energy analysis. In fact, the sensitivity analysis was used to solely investigate the impact of several factors on the NEB namely; energy consumption of bioethanol production process, farm energy inputs, transportation energy consumption, and cassava yield.

As shown in Figure 2, a $10 \%$ rise in energy consumption during the ethanol production process was estimated to result in $7.66 \%$ reduction in NEB. On the contrary, NBE is increased by $1.3 \mathrm{MJ} / \mathrm{L}$ when energy consumption during ethanol production process is reduced by $10 \%$. Though the magnitude of energy saving is small, when total amount of CFE production (assumed to be $1 \mathrm{ML} / \mathrm{d}$ ) was accounted, its effects on energy savings would be significant. The growth in the energy consumption in the transportation stage would result in a $0.61 \%$ reduction in NEB and vice versa. Meanwhile, $10 \%$ rise in the energy used in the cultivation stage reduced the energy balance by $2 \%$, or $0.34 \mathrm{MJ} / \mathrm{L}$, and vice versa. The contributions of the above-mentioned stages considering the total energy used in the CFE production is not significant compared with the cassava yield which had the most significant effect on NEB. More specifically, a $10 \%$ increase in cassava yield would lead to $10.27 \%$ increase in NEB, 
equivalent to $1.74 \mathrm{MJ} / \mathrm{L}$ of energy savings, and vice versa. Overall, in the CFE production process, ethanol production energy consumption and cassava yield were found as the most important stages. Therefore, improvements should be targeted to increase the ethanol production efficiency as well as to implement cassava cultivation practices to increase crops yield.

\section{Cassava yield}

Transportation

Ethanol production

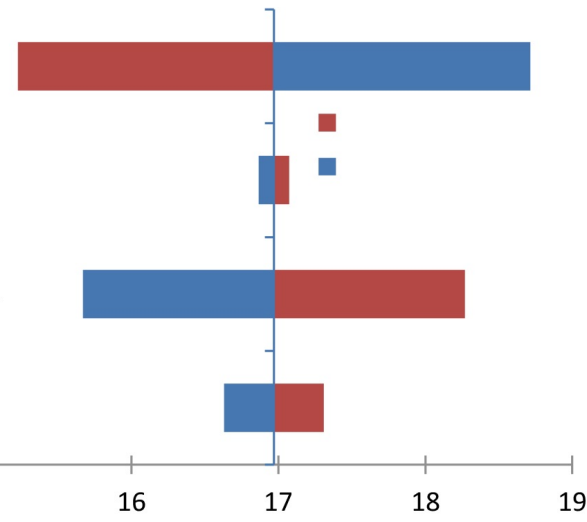

Net energy balance (NEB; MJ/L)

Fig.2. Sensitivity analysis of the factors related to the net energy balance (NEB)

\subsection{GHG emission reduction}

The GHG balance of the CFE system shown in Table 7 indicates that CFE production and distribution in Malaysia as a substitute for conventional gasoline, could result in significant GHG emissions reductions. More specifically, the production and distribution of $1 \mathrm{~L} \mathrm{CFE}$ could reduce $1.9 \mathrm{~kg}$ of $\mathrm{CO}_{2}$ eq emission and prevent total emissions by $73.5 \%$.

Table 7 presents the fraction of GHG production by stage. As predicted, ethanol production process produced the highest GHG emissions, i.e., $72.09 \%$ of the total life cycle GHG emissions. This was consistent with the NEB analysis, and was due to the high consumption of fossil fuels. The other stages, i.e., cassava cultivation and transportation both contributed $12.9 \%$ of the total GHG emissions. Moreover, the GHG emissions related to the fossil energy consumption to support human labor accounted for almost $62 \%$ of total emissions related to cassava cultivation process. This was ascribed to the fact that most of the farming activities were performed manually.

\subsection{Comparison of energy balance and GHG emission}

Comparison of energy balance and GHG emissions for different bioethanol feedstocks and country are presented in Table 8. In summary, sugar cane's ethanol in Brazil was found to be most favourable in terms of energy and environment, with NEB of $33.4 \mathrm{MJ} / \mathrm{L}$ and $90.9 \%$ emission reduction (Macedo et al., 2004). It was then followed by Sri Kanji 1 cassava in Malaysia with NEB and emission reduction of $25.7 \mathrm{MJ} / \mathrm{L}$ and $73.5 \%$, respectively. Based on the results obtained herein, bioethanol production from Sri Kanji 1 cassava in
Malaysia resulted in higher energy and GHG savings compared with cassava bioethanol produced in China (Nguyen et al., 2007) and Thailand (Dai et al., 2006), and corn bioethanol in the USA (Shapouri et al., 2004). These differences are due to the high root yield of Sri Kanji 1 of about 92.9 $\mathrm{t} / \mathrm{ha}$, which is much higher than the normal cassava variety with the highest reported root yield of below $30 \mathrm{t} / \mathrm{ha}$.

Table 7.

GHG balance of bioethanol production from Sri Kanji 1 cassava in Malaysia.

\begin{tabular}{lll}
\hline Items & $\mathrm{g} \mathrm{CO}_{2} \mathrm{eq}^{\mathrm{a}} / \mathrm{L} \mathrm{EtOH}$ & $\begin{array}{l}\text { Contribution } \\
(\%)\end{array}$ \\
\hline Cassava cultivation & $\mathbf{8 9}$ & $\mathbf{1 2 . 9 3}$ \\
Fertilizers & 24 & - \\
Herbicides & 2 & - \\
Diesel fuel & 8 & - \\
Labor & 55 & - \\
Ethanol production & $\mathbf{4 9 6}$ & $\mathbf{7 2 . 0 9}$ \\
Transportation & $\mathbf{8 9}$ & $\mathbf{1 2 . 9 4}$ \\
Other GHG emissions & $\mathbf{1 4}$ & $\mathbf{2 . 0 3}$ \\
\hline Soil $\mathrm{N}_{2} \mathrm{O}$ & 7 & - \\
CH & & - \\
\hline Total GHG $\mathrm{N}_{2} \mathrm{O}$ from biogas combustion & 7 & - \\
Gasoline fuel-cycle GHG emissions & $\mathbf{2 , 9 1 8}$ & - \\
Gross avoided emissions & $\mathbf{- 2 , 9 1 8 \times 0 . 8 9 = - 2 , 5 9 7}$ & - \\
Net avoided emissions & $\mathbf{- 2 , 5 9 7 + 6 8 8 = - 1 , 9 0 9}$ & - \\
Total GHG saving (\%) & $\mathbf{7 3 . 5 \%}$ & - \\
\hline
\end{tabular}

\section{Conclusions}

Through this study, bioethanol production from Sri Kanji 1 in Malaysia was found to be energy efficient with a positive NEB value of $25.68 \mathrm{MJ} / \mathrm{L}$. More specifically, if CFE is implemented in Malaysia with a production capacity of $1 \mathrm{ML} / \mathrm{yr}$, it could save about $240 \mathrm{ML}$ of conventional gasoline annually. In terms of the environmental impacts, CFE could play a great role in reducing GHG emissions by more than $73 \%$ compared with conventional gasoline. Overall, based on the results of this study, it could be concluded that the implementation of bioethanol production from Sri Kanji 1 cassava in Malaysia would be feasible in terms of both energy efficiency and environmental benignity.

\section{Acknowledgements}

The authors would like to acknowledge the support by Fundamental Research Grant Scheme (FRGS) through the Ministry of Higher Education of Malaysia (MOHE) with a reference number FRGS/1/2015/TK07/UNITEN/01/1.

Table 8.

Comparison of energy balance and GHG emission for different bioethanol feedstocks and country.

\begin{tabular}{|c|c|c|c|c|c|c|}
\hline Feedstock & Country & Net fossil inputs $(\mathrm{MJ} / \mathrm{L})$ & $\begin{array}{l}\text { Total GHG emissions } \\
\quad\left(\mathrm{g}_{\mathrm{CO} 2 \mathrm{q}} / \mathrm{L}_{\mathrm{EOH}}\right)\end{array}$ & NEB $(M J / L)$ & Emission reduction (\%) & Reference \\
\hline Cassava & China & 13.30 & 1,538 & 21.1 & 23.3 & Leng et al. (2008) \\
\hline Cassava & Thailand & 12.06 & 964 & 22.34 & 62.9 & Nguyen et al. (2007) \\
\hline Corn & USA & 12.76 & 1,506 & 21.64 & 48.4 & Shapouri et al. (2004) \\
\hline Sugarcane & Brazil & 0.96 & 256 & 33.44 & 90.9 & Macedo et al. (2004) \\
\hline Cassava & Malaysia (this study) & 8.72 & 688 & 25.68 & 73.5 & This study \\
\hline
\end{tabular}

Please cite this article as: Hanif M., Mahlia T.M.I., Aditiya H.B., Abu Bakar M.S. Energy and environmental assessments of bioethanol production from Sri Kanji 1 cassava in Malaysia. Biofuel Research Journal 13 (2017) 537-544. 10.18331/BRJ2017.4.1.3 
References

[1] Audsley, E., Stacey, K.F., Parsons, D.J., Williams, A.G., 2009. Estimation of the greenhouse gas emissions from agricultural pesticide manufacture and use. Cranfield University, Bedford.

[2] Belboom, S., Bodson, B., Léonard, A., 2015. Does the production of Belgian bioethanol fit with European requirements on GHG emissions? case of wheat. Biomass Bioenergy. 74, 58-95.

[3] Biograce, 2011. List of additional standard values, Europe: Intelligent Energy.

[4] Cassava Farming Package, 2012. Horticulture Division of Agriculture, Ministry of Agriculture and Agro-based Industry Malaysia.

[5] Cooney, C.P., Worm, J.J. Naber, J.D., 2009. Combustion characterization in an internal combustion engine with ethanol-gasoline blended fuels varying compression ratios and ignition timing. Energy Fuels. 23(5), 2319-2324.

[6] Curtis, S., Owen, M., Hess, T., Egan, S., 2008. Effect of ethanol blends on a spark ignition, 4-stroke, internal combustion engine. Brigham Young University, Provo, Utah.

[7] Dai, D., Hu, Z., Pu, G., Li, H., Wang, C., 2006. Energy efficiency and potentials of cassava fuel ethanol in Guangxi region in China. Energy Convers. Manage. 47(13-14), 1686-1699.

[8] EPA, 2014. Emission Factors for Greenhouse gas Inventories.

[9] Farrell, A.E., Plevin, R.J., Turner, B.T., Jones, A.D., O'hare, M., Kammen, D.M., 2006. Ethanol can contribute to energy and environmental goals. Science. 311(5760), 506-508.

[10] Frazier, R.S., Ethanol gasoline blends and small engines. Oklahoma Cooperative Extension Service, Oklahoma State University.

[11] Guinee, J.B., 2002. Handbook on Life Cycle Assessment Operational Guide to the ISO standards. Int. J. Life Cycle Assess. 7(5), 311-313.

[12] Helsel, Z.R., 1992. Energy and Alternatives for fertilizer and Pesticide use, in: Fluck, R.C. (ed.), Energy in Farm Production. Elsevier, pp. 177201.

[13] Henke, J.M., Klepper, G., Schmitz, N., 2005. Tax examption for biofuels in Germany: is bio-ethanol really an option for climate policy. Energy. 30(14), 2617-2635

[14] Husnawan, M., Masjuki, H.H., Mahlia, T.M.I., Mekhilef, S., Saifullah, M.G., 2009a. Use of post flame metal-based and oxygenated additive combination for biodiesel-diesel blends. J. Sci. Ind. Res. 68(12), 10491052 .

[15] Husnawan, M., Masjuki, H.H., Mahlia, T.M.I. Saifullah, M.G., 2009b. Thermal analysis of cylinder head carbon deposits from single cylinder diesel engine fueled by palm oil-diesel fuel emulsions. Appl. Energy. 86(10), 2107-2113.

[16] IFAS, The Energy Information Handbook. 1991, Gainsesville: Florida Cooperative Extension Service, Institute of Food and Agricultural Sciences, University of Florida.

[17] ISO 14040, 2006. Technical Committee ISO/TC 207, Environmental management - life cycle assessment - principle and framework. International Organization for Standardization (ISO).

[18] ISCC, 2011. GHG emissions calculation methodology and GHG audit. International Sustainability and Carbon Certification.

[19] Jayed, M.H., Masjuki, H.H., Kalam, M.A., Mahlia, T.M.I., Husnawan, M., Liaquat, A.M., 2011. Prospects of dedicated biodiesel engine vehicles in Malaysia and Indonesia. Renew. Sust. Energy Rev. 15(1), 220-235

[20] Kalam, M.A., Saifullah, M.G., Masjuki, H.H., Husnawan, M., Mahlia, T.M.I., 2008. PAH and other emissions from coconut oil blended fuels. J. Sci. Ind. Res. 67, 1031-1035

[21] Khatiwada, D., Venkata, B.K., Silveira, S., Johnson, F.X., 2016. Energy and GHG balances of ethanol production from cane molasses in Indonesia. Appl. Energy. 164, 756-768.

[22] Kim, S., Dale, B., 2006. Ethanol fuels: E10 or E85-life cycle perspective. Int. J. Life Cycle Assess. 11(2), 117-121.

[23] Kuakoon, P., 2011. Cassava bioethanol production in South-South technology transfer: ethanol production from Cassava. Bangkok.

[24] Leng, R., Wang, C., Zhang, C., Dai, D., Pu, G., 2008. Life cycle inventory and energy analysis of cassava-based fuel ethanol in China. J. Cleaner Prod. 16(3), 374-384.
[25] Lim, S., Teong, L.K., 2010. Recent trends, oppoturnities and challenges of biodiesel in malaysia: an overview. Renew. Sust. Energy Rev. 14(3), 938-954.

[26] Macedo, I.D.C., Leal, M.R.L.V., Da Silva, J.E.A.R., 2004 Assessment of GHG emissions in the production and use of fue ethanol in Brazil. Secretariat of the environment. Government of the State of Sao Paulo. Brazil.

[27] Mahlia, T.M.I., Tohno, S., Tezuka, T., 2012a. A global review of success story on implementation of fuel economy standard for passenger cars: lesson for other countries.Energy Educ. Sci. Technol. A: Energy Sci. Res. 29(2), 947-972.

[28] Mahlia, T.M.I., Tohno, S., Tezuka, T., 2012b. A review on fuel economy test procedure for automobiles: implementation possibilities in Malaysia and lessons for other countries. Renew. Sust. Energy Rev. 16(6), 4029-4046.

[29] Malaysia Energy Commission., 2011. Malaysia Energy Information Hub.

[30] Mardi. Malaysia Agriculture Research and Development Institute.

[31] Masjuki, H.H., Kalam, M.A., Syazly, M., Mahlia, T.M.I., Rahman, A.H., Redzuan, M., Varman, M., Saidur, R., Yau, Y.H., 2006. Experimental evaluation of an unmodified diesel engine using biodiesel with fuel additive. IFOST 2006 (1st International Forum on Strate gic Technology), Proceedings, 96-99.

[32] Milnes, R., Deller, L., Hill, N., 2010. Ethanol internal combustion engine. Energy Technology Systems Analysis Programme, United Kingdom. 1-6.

[33] National energy balance, 2012. Malaysia: Ministry of Energy, Green Technology and Water. Putrajaya.

[34] National Research Council, 2010. Technologies and approaches to reducing the fuel consumption of medium-and heavy-duty vehicles. National Academies Press.

[35] Nguyen, T.L.T., Gheewala, S.H., Garivait, S., 2007. Energy balance and GHG-abatement cost of cassava utilization for fuel ethanol in Thailand. Energy Policy. 35(9), 4585-4596.

[36] Nguyen, T.L.T., Gheewala, S.H., 2008. Life cycle assessment of fuel ethanol from cassava in Thailand. Int. J. Life Cycle Assess. 13(2), 147-154.

[37] Numjuncharoen, T., Papong, S., Malakul, P., Mungcharoen, T., 2015. Life-cycle GHG emissions of cassava-based bioethanol production. Energy Procedia. 79, 265-271.

[38] NurulNahar, E., Tan, S.L., 2012. Cassava mini-cuttings as a source of planting material. J. Trop. Agric. Fd. Sc. 40(1), 145-151.

[39] Odum, H.T., 1983. System ecology. New York. Wiley.

[40] Ong, H.C., Mahlia, T.M.I. Masjuki, H.H., 2012. A review on energy pattern and policy for transportation sector in Malaysia. Renew. Sust. Energy Rev. 16(1), 532-542.

[41] Ong, H.C., Masjuki, H.H., Mahlia, T.M.I., Silitonga, A.S., Chong, W.T., Leong, K.Y., 2014. Optimization of biodiesel production and engine performance from high free fatty acid Calophyllum inophyllum oil in CI diesel engine. Energy Convers. Manage. 81, 3040 .

[42] Ozkan, B., Akcaoz, H., Fert, C., 2004. Energy input-output analysis in Turkish agriculture. Renew. Energy. 29(1), 39-51.

[43] Romanelli, T.L., Milan, M., 2005. Energy balance methodology and modeling of supplimentary forage production for cattle in Brazil. Scientia Agricola. 62(1), 1-7.

[44] Sarkar, M.S.K., Begum, R.A., Pereira, J.J., Jaafar, A.H., 2013. Trends of energy demand and supply as well as GHG emissions in Malaysia. 2nd International Conference on Agricultural, Environment and Biological Sciences. Pattaya (Thailand).

[45] Schifter, I., Diaz, L., Rodriguez, R., Gómez, J.P., Gonzalez, U., 2011. Combustion and emissions behavior for ethanol-gasoline blends in a single cylinder engine. Fuel. 90(12), 3586-3592.

[46] Shapouri, H., Duffield, J., McAloon, A., Wang, M., 2004. The 2001 net energy balance of corn ethanol. US Department of Agriculture, Washington, DC

[47] Siddegowda, K.B., Venkatesh, J., 2013. Performance and emission characteristic of MPFI engine using gasoline-ethanol blends. Int. J. Innovative Res. Sci. Eng. Technol. 2(9), 4891-4897. 
[48] Silalertruksa, T., Gheewala, S.H., 2009. Environmental sustainability assessment of bio-ethanol production in Thailand. Energy. 34(11), 1933 1946.

[49] Silitonga, A.S., Masjuki, H.H., Mahlia, T.M.I., Ong, H.C., Chong, W.T., 2013. Experimental study on performance and exhaust emissions of a diesel engine fuelled with Ceiba pentandra biodiesel blends. Energy Convers. Manage. 76, 828-836.
[50] Sorapipatana, C., Yoosin, S., 2011. Life cycle cost of ethanol production from cassava in Thailand. Renew. Sust. Energy Rev. $15(2), 1343-1349$.

[51] Wang, K., Yang, X., Ren, X., Zhang, J., Mao, Z., 2016. Development of a new cleaner production process for cassava ethanol. Chin. J. Chem. Eng. (http://dx.doi.org/10.1016/j.cjche.2016.10.002).

[52] Wang, M., 2006. Greet 1.7 Beta - transportation fuel cycle model. US Department of Energy, Argonne National Laboratory, Argonne, IL. 